\title{
ANALYSIS OF STUDENTS' MISTAKES IN SOLVING CIRCLE PROBLEM IN CLASS XI MIPA 2 SMAN 1 BANGKINANG KOTA
}

\section{ANALISIS KESALAHAN SISWA DALAM MENYELESAIKAN SOAL LINGKARAN DI KELAS XI MIPA 2 SMAN 1 BANGKINANG KOTA}

\author{
Miseriyati $^{1)}$, Ravina Faradilla Syahril ${ }^{2)}$ \\ ${ }^{1)}$ SMA Negeri 1 Bangkinang Kota \\ ${ }^{2)}$ Pendidikan Matematika, Universitas Riau \\ Email : miseriyati@gmail.com
}

Submitted: (25 Mei 2020); Accepted: (28 Mei 2020);

Published: (31 Mei 2020)

\begin{abstract}
This study aimed to determine student's mistakes in solving mathematical problems on the circle in SMAN 1 Bangkinang Kota. This research is a qualitative descriptive study. This research subjects consisted of 34 students consisting of 12 boys and 22 girls. The technique of data collection using a written test. The research instrument used was a learning achievement test consisting of 6 items made by the teacher and based on Basic Competency 3.3 analyze circle analytically. Basic Competency 3.3 developed into six Indicators of Competency Achievement. Each item measures different Indicators of Competency Achievement. Student's answers were analyzed descriptively qualitatively by looking at the type of mistake students made on each item. The result showed that mistakes made by students were fact errors, concept errors, principle errors, and operating errors. The mistakes made by students are caused by students not being careful in solving problems and not understanding the rules of algebraic operations. This research result is the kind mistakes of most students do is operating errors as much as 46,47\%; then students do concept errors as much as 33,80\%; principle errors as much as 15,49\%; and fact errors as much as 4,22\%.
\end{abstract}

Keywords : Student's errors analyze, Fact, Concept, Principle, Operating, Circle

\section{PENDAHULUAN}

Matematika merupakan salah satu cabang ilmu yang mendasari kehidupan manusia. Aplikasi matematika yang paling sederhana yang digunakan dalam kehidupan manusia seperti operasi hitung penjumlahan, pengurangan, perkalian dan pembagian. Melihat pentingnya matematika dalam kehidupan, maka matematika perlu untuk diajarkan di setiap jenjang kehidupan. Melalui pembelajaran matematika di sekolah, diharapkan siswa mampu mengembangkan kemampuan berpikirnya dalam memecahkan masalah.

Pembelajaran secara umum adalah upaya guru untuk menciptakan iklim dan pelayanan terhadap kemampuan, potensi, minat, bakat, dan kebutuhan siswa yang amat beragam agar terjalin interaksi optimal antara guru dan siswa serta antara siswa dan siswa (Hamdani, 2011). Sementara pembelajaran menurut Rusman (2016) merupakan suatu sistem yang terdiri atas berbagai komponen yang saling berhubungan satu sama lain. Komponen tersebut meliputi tujuan, materi, metode dan evaluasi. sedangkan salah satu keberhasilan kegiatan pembelajaran bergantung pada tercapai atau tidaknya tujuan pembelajaran.

Pembelajaran matematika berdasarkan permendikbud nomor 59 tahun 2014 bertujuan antara lain agar peserta didik (1) memahami konsep matematika; (2) mampu menggunakan pola dalam penyelesaian masalah; (3) menggunakan penalaran dalam pemecahan masalah; (4) mengomunikasikan gagasan; (5) memiliki sikap menghargai kegunaan matematika dalam kehidupan yang sesuai dengan nilai-nilai dalam matematika dan pembelajarannya; (7) melakukan kegiatankegiatan motorik yang menggunakan pengetahuan matematika; (8) menggunakan alat peraga untuk melakukan kegiatan-kegiatan matematik. 
Berdasarkan Permendikbud nomor 59 tahun 2014 tersebut dapat diketahui bahwa pembelajaran matematika senantiasa melatih cara berfikir siswa dalam memahami konsep matematika, bernalar, memecahkan masalah dan mengomunikasikan gagasan sesuai nilainilai dalam matematika. Agar tercapainya tujuan pembelajaran ini maka guru sebagai pemegang peran penting dalam proses pembelajaran di kelas harus mempu menciptakan kondisi pembelajaran yang berkualitas dan mampu meningkatkan pemahaman siswa sehingga siswa akan lebih aktif dan mampu menguasai materi pembelajaran.

Terkait dengan pembelajaran matematika, masih banyak siswa yang mengalami kesulitan dalam memahami materi matematika, sehingga siswa sering melakukan kesalahan dalam menyelesaikan soal matematika. Penyebab kesalahan atau kesulitan siswa antara lain: (1) memahami masalah atau apa maksud dari masalah yang diberikan, (2) memahami apa yang ditanyakan atau kurangnya pemahaman siswa untuk mengaitkan masalah dengan materi yang terkait dengan masalah (Alviana, 2018). Terkadang kesalahan yang sering ditemui dalam belajar matematika yakni siswa sering membuat kesalahan pada perhitungan dalam menyelesaikan masalah. Ariyana, Fera, \& Febrian (2019) mengatakan bahwa kesalahankesalahan yang sering dilakukan siswa diantaranya kesalahan menafsirkan konsep, kurang tepat menggunakan rumus, dan kesalahan pada sistematika menyelesaikan soal.

Menurut Wijaya \& Masriyah (2013) kesalahan merupakan bentuk penyimpangan terhadap suatu hal yang telah dianggap benar atau terhadap sesuatu yang sebelumnya telah disepakati. Dalam matematika, kesalahan siswa dalam memahami suatu konsep akan berpengaruh kepada konsep pada materi selanjutnya. Matematika merupakan ilmu yang sistematis, jika siswa mengalami kesalahan pada langkah kedua, maka sampai langkah ketiga, keempat dan seterusnya juga akan mengalami kesalahan. Hal seperti ini sering kali ditemui dalam pembelajaran disekolah, sehingga terkadang bisa mempengaruhi hasil belajar matematika siswa.

Hasil belajar matematika merupakan salah satu indikator yang dapat mengukur berhasil atau tidaknya seorang siswa dalam memahami suatu materi dalam pembelajaran matematika. Hasil belajar menurut Dimyanti dan Mudjiono (Nurhazannah, 2017) merupakan hasil yang dicapai dalam bentuk angka-angka atau skor setelah diberikan tes hasil belajar pada akhir pembelajaran. Kesalahan siswa dalam menyelesikan soal matematika menjadi salah satu faktor yang mempengaruhi hasil belajar matematika siswa. Dengan demikian, kesalahan itu perlu untuk diidentifikasi dengan tujuan untuk mendapatkan informasi tentang jenis kesalahan tersebut, sehingga membantu siswa untuk mengatasi kesulitan dalam belajar matematika.

Kesulitan yang dialami siswa dalam menyelesaikan masalah tidak hanya dialami oleh siswa yang mempunyai kemampuan akademik rendah aja, akan tetapi dapat dialami oleh siswa yang tingkat kemampuan akademik sedang dan rendah atau jenis kemampuan yang beragam. Kesulitan belajar matematika sebagian besar dipengaruhi oleh kesulitan siswa dalam memahami soal dan menyelesaikan soal matematika. Hal ini dapat dilihat dari kesalahan yang dilakukan siswa dalam menyelesaikan soal.

Kesalahan siswa dalam menyelesaikan soal matematika bukan hanya memperlihatkan kesulitan siswa dalam pembelajaran, tetapi juga mengungkapkan bahwa adanya kekurangan selama proses pembelajaran. Sehingga dengan mengetahui kesalahan yang dilakukan siswa dalam menyelesaikan soal matematika, maka guru dapat menjadikan permasalahan ini sebagai langkah awal dalam usaha untuk memperbaiki dan meningkatkan kualitas pembelajaran (Zaini, 2010). Oleh karena itu, guru harus mengetahui kesalahankesalahan dalam pembelajaran dengan mengidentifikasi dan menganalisis kesalahan siswa untuk memperbaiki kualitas pembelajaaran.

Alviana (2017) mengatakan bahwa beberapa kesalahan yang dilakukan siswa dalam mengerjakan soal matematika adalah (1) kesalahan dalam memahami soal; (2) kesalahan membuat rencana; (3) kesalahan 
dalam melaksanakan atau menyelesaikan model matematika; (4) kesalahan menulis atau menyatakan jawaban akhir. Sedangkan Soedjadi (2000) mengelompokkan kesalahan siswa dalam menyelesaikan soal matematika menjadi empat yaitu, kesalahan fakta, kesalahan konsep, kesalahan prinsip dan kesalahan operasi. Hal ini sejalan dengan pendapat Fitria (2013) dengan mengelompokkan kesalahan siswa menjadi empat jenis kesalahan yaitu fakta, konsep, prinsip dan operasi.

Jenis-jenis kesalahan yang dianalisis dalam penelitian ini menggunakan pengelompokan kesalahan siswa menurut Fitria (2013) yaitu kesalahan fakta, konsep, prinsip dan operasi. Menurut Suhady, Roza, \& Maimunah (2019) kesalahan fakta yaitu kesalahan siswa dalam menuis simbol, notasi dan aturan suatu operasi serta salah dalam menulis yang diketahui dan ditanya. Kesalahan konsep yaitu kesalahan siswa dalam menyatakan konsep-konsep yang terkait meliputi ide abstrak untuk menjelaskan yang contoh dan bukan contoh atau dapat berupa definisi. Kesalahan prinsip yaitu kekeliruan dalam beberapa fakta atau beberapa konsep seperti kesalahan dalam menggunakan rumus. Sedangkan kesalahan operasi adalah kesalahan dalam melakukan perhitungan seperti kesalahan dalam pengoperasian penjumlahan, pengurangan, perkalian dan pembagian serta dalam pengerjaan aljabar.

Menurut Krismanto cara yang dapat dilakukan untuk mengetahui siswa yang mengalami kesulitan belajar salah satunya adalah dengan melakukan analisis hasil ulangan dengan melihat sifat kesalahan yang dibuat (Wardi, 2015). Terkait pendapat tersebut maka perlu dilakukannya analisis terhadap kesalahan yang dilakukan siswa dalam menjawab soal agar guru dapat memilih strategi yang tepat sehingga siswa tidak melakukan kesalahan yang sama pada materi selanjutnya.

Analisis kesalahan menurut Saifudin (2017) merupakan proses meninjau tanggapan siswa untuk mengidentifikasi pola kesalahpahaman. Sedangkan Ashlock (Damayanti, Mayangsari, \& Mahardhika, 2017) menyatakan bahwa analisis kesalahan adalah proses menganalisis pekerjaan siswa untuk mengetahui mengapa siswa menyelesaikan suatu masalah kurang tepat. Analisis kesalahan merupakan suatu upaya yang dilakukan untuk mengetahui penyebab kesalahan yang dilakukan siswa dalam menyelesaikan masalah atau soal yang diberikan oleh guru. Oleh karena itu, seorang guru harus mampu memahami kesalahan yang dialami siswanya, mencoba untuk menjelaskan apa yang mereka alami, dan menemukan apa yang menyebabkan kesalahan itu terjadi.

Salah satu materi yang diajarkan pada kelas XI untuk peminatan IPA sesuai materi kurikulum 2013 adalah lingkaran. Pada materi lingkaran biasanya siswa hanya menyelesaikan soal secara prosedural berdasarkan contohcontoh soal yang telah diberikan guru, dan siswa juga sering salah dalam menggunakan rumus untuk menyelesaikan soal. Hal ini menyebabkan siswa banyak melakukan kesalahan dalam menyelesaikan soal. Selain itu Ariyana, Fera, \& Febrian (2019) menyatakan bahwa dalam menyelesaikan soal lingkaran kesalahan yang sering dilakukan siswa diantaranya tidak membuat kesimpulan, kesalahan dalam memilih prosedur penyelesaian, kesalahan dalam menuliskan rumus, menyesuaikan informasi dengan simbolnya, kesalahan dalam menggunakan rumus dan tidak menyelesaikan soal karena tidak ingat rumus.

\section{METODE}

Penelitian ini bertujuan untuk mendeskripsikan secara kualitatif data dengan cara menganalisis kesalahan-kesalahan siswa dalam menyelesaikan soal pada materi lingkaran. Penelitian deskriptif kualitatif menurut Sukmadinata (2011) adalah menyelidiki bentuk, kegiatan, sifat, perubahan, kaitan, persamaan dan beda suatu kejadian dengan kejadian lainnya yang bertujuan untuk memaparkan kejadian-kejadian tersebut, baik yang bersifat alamiah maupun hasil rekayasa . Tahap pertama menetapkan 6 soal buatan guru pada materi lingkran yang diberikan kepada siswa untuk diselesaikan secara tertulis. Tahap kedua pelaksanaan pemberian soal yang dilakukan pada saat siswa melaksanakan ulangan harian materi lingkaran yang 
dikerjakan secara individu. Tahap ketiga menganalisis hasil kerja siswa dengan mengelompokkan berdasarkan jenis kesalahan dari keenam soal serta dikaji kesalahan fakta, konsep, prinsip dan operasi.

Subjek dalam penelitian ini adalah siswa kelas XI MIPA 2 SMAN 1 Bangkinang Kota tahun ajaran 2019/2020 sebanyak 34 siswa, yang terdiri dari 12 siswa laki-laki dan 22 siswa perempuan dengan kemampuan tinggi, sedang dan rendah. Instrumen penelitian yang digunakan adalah tes hasil belajar pada materi lingkaran yang terdiri dari 6 soal uraian yang dibuat oleh guru matematika dan mengacu pada KD 3.3 Menganalisis lingkaran secara analitik. Kompetensi Dasar (KD) dikembangkan menjadi Indikator Pencapaian Kompetensi (IPK). Masing-masing butir soal mengukur satu IPK yang berbeda.

\section{HASIL DAN PEMBAHASAN}

Pelaksanaan tes hasil belajar dilakukan pada hari Senin tanggal 24 Februari 2020 bertepatan dengan pelaksanaan ulangan harian. Hasil analisis dari jenis kesalahan yang dilakukan siswa seperti pada tabel berikut ini.

Tabel 1. Penggolongan Jenis Kesalahan Siswa

\begin{tabular}{|c|c|c|c|c|c|}
\hline \multirow{2}{*}{$\begin{array}{c}\text { Butir } \\
\text { Soal }\end{array}$} & \multicolumn{4}{|c|}{ Total Kesalahan } & \multirow{2}{*}{ Total } \\
\hline & Fakta & Konsep & Prinsip & Operasi & \\
\hline 1 & - & 9 & 6 & 7 & 22 \\
\hline 2 & - & 3 & - & 10 & 13 \\
\hline 3 & - & 4 & - & 3 & 7 \\
\hline 4 & - & - & 5 & 3 & 8 \\
\hline 5 & - & 5 & - & 5 & 10 \\
\hline 6 & 3 & 3 & - & 5 & 11 \\
\hline Jumlah & 3 & 24 & 11 & 33 & 71 \\
\hline Persent & 4,22 & 33,80 & 15,49 & 46,47 & \\
\hline ase & $\%$ & $\%$ & $\%$ & $\%$ & \\
\hline
\end{tabular}

Tabel 1 menunjukkan bahwa pada soal nomor 1, terdapat 9 orang siswa melakukan kesalahan konsep, 6 siswa melakukan kesalahan prinsip dan 7 siswa melakukan kesalahan dalam pengoperasian. Pada soal nomor 2, terdapat 3 siswa melakukan kesalahan konsep dan 10 siswa melakukan kesalahan operasi. Pada soal nomor 3, 4 siswa melakukan kesalahan konsep dan 3 siswa melakukan kesalahan operasi. Pada soal nomor 4, terdapat 5 orang siswa melakukan kesalahan prinsip dan 3 siswa melakukan kesalahan operasi. Pada nomor 5, 5 orang siswa melakukan kesalahan konsep dan 5 orang siswa melakukan kesalahan dalam pengoperasian. Pada soal nomor 6, terdapat 3 orang siswa yang melakukan kesalahan fakta, 3 siswa melakukan kesalahan konsep dan 5 siswa melakukan kesalahan operasi.

Berdasarkan tabel 1 tersebut, terlihat bahwa kesalahan operasi merupakan kesalahan yang paling sering dilakukan siswa. Hal ini dapat dilihat dari persentase kesalahan operasi yang dilakukan siswa menunjukkan persentase yang tertinggi yaitu 46,47\%. Kesalahan yang paling banyak ditemukan selanjutnya adalah kesalahan siswa dalam menggunakan konsep yaitu sebanyak 33,80\% dan kesalahan siswa dalam menggunakan prinsip yaitu $15,49 \%$. Dari keempat kesalahan yang dilakukan siswa, tampak bahwa jenis kesalahan fakta merupakan kesalahan yang paling sedikit terjadi yaitu $4,22 \%$.

Adapun bentuk kesalahan-kesalahan yang dilakukan siswa dalam menggunakan fakta, konsep, prinsip dan operasi dapat dilihat pada uraian berikut ini.

Indikator 1: Menentukan persamaan Lingkaran yang berpusat di $P(a, b)$ dan melalui titik $A(x, y)$

\section{Soal :}

1. Tentukan persamaan Lingkaran yang berpusat di titik $P(2,-3)$ dan melalui titik $A(-1,2)$.

Pada indikator 1, peneliti melihat bahwa sebagian siswa mampu menjawab soal dengan tepat dan benar. Namun, masih terdapat beberapa siswa yang melakukan kesalahan. Kesalahan yang dilakukan siswa pada indikator ini adalah kesalahan konsep, prinsip dan kesalahan operasi. Siswa dapat menuliskan prinsip awal dengan benar, namun siswa melakukan kesalahan konsep dalam membedakan antara titik pusat lingkaran dan titik yang dilalui oleh lingkaran, yang dapat dilihat pada Gambar 1 (a). Kemudian ditemukan pula siswa yang menggunakan prinsip awal yang benar, namun ketika menentukan persamaan akhir, siswa salah dalam menyatakan prinsip seperti pada Gambar 1 (b) dan 1 (c). Selain itu, kesalahan yang juga ditemukan adalah kesalahan konsep seperti pada Gambar 1 (c) dan (d), Kesalahan 
operasi seperti pada Gambar 1 (e).

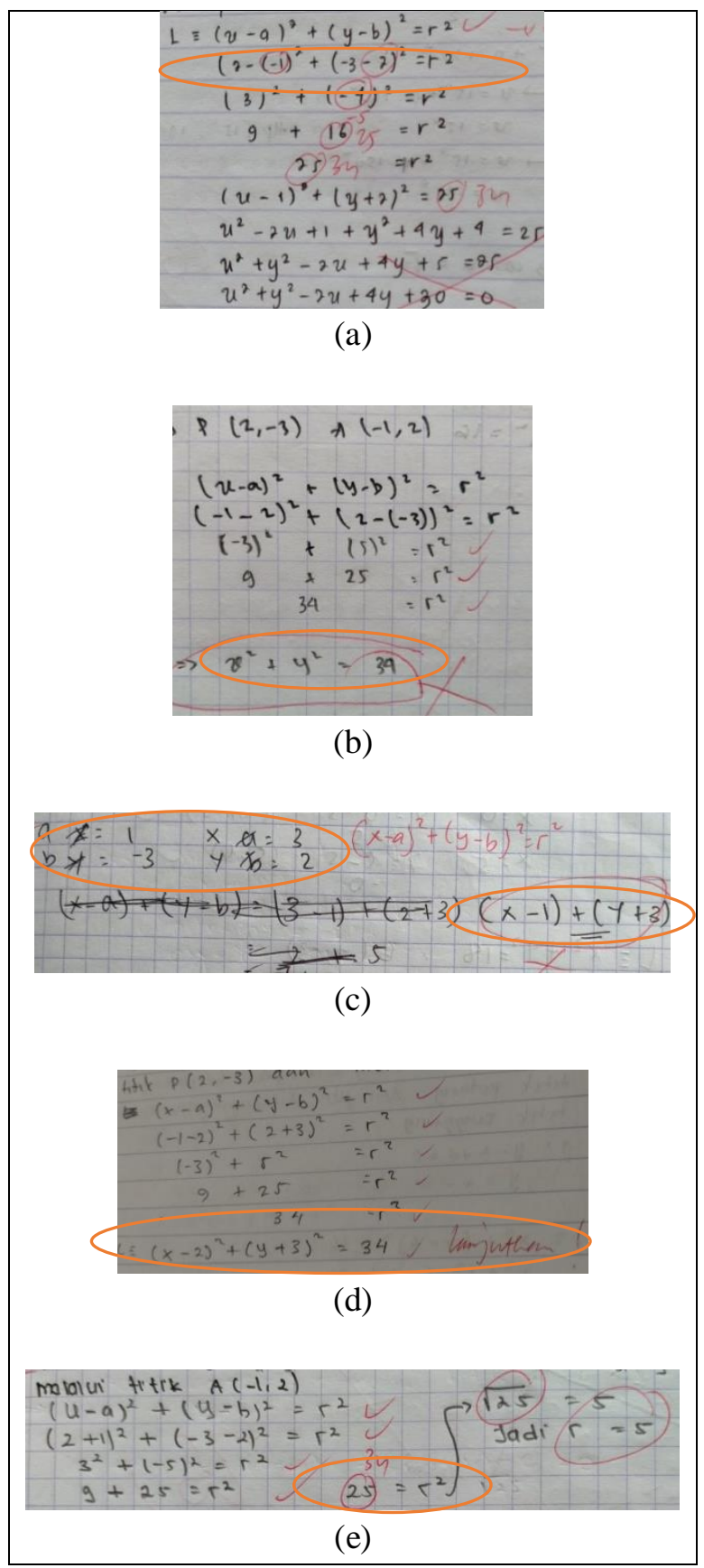

Gambar 1. Contoh Kesalahan Konsep, Prisip dan Operasi pada Soal Nomor 1

Pada Gambar 1 (a), siswa salah dalam membedakan titik pusat dan titik yang dilalui lingkaran. sehingga siswa salah dalam memasukkan angka ke dalam rumus. Kesalahan di langkah awal yang dilakukan siswa ini menyebabkan semua langkahlangkah selanjutnya menjadi salah.
Jawaban siswa pada Gambar 1 (c) merupakan salah satu kesalahan konsep dan prinsip. Kesalahan yang sama seperti Gambar 1 (a) siswa salah menggunakan konsep dalam membedakan titik pusat dan titik yang dilalui lingkaran, selain itu siswa juga salah dalam menggunakan prinsip. Selanjutnya, salah satu kesalahan konsep yang banyak dilakukan siswa, dapat dilihat seperti Gambar 1 (d). Siswa tidak melanjutkan jawabannya sampai selesai.

Indikator 2: Mentukan pusat dan jari-jari lingkaran, jika yang diketahui adalah bentuk umum lingkaran $\mathrm{L} \equiv x^{2}+y^{2}+A x+\mathrm{B} y+$ $\mathrm{C}=0$.

\section{Soal :}

2. Tentukan pusat dan jari-jari lingkaran $\mathrm{L} \equiv$ $x^{2}+y^{2}-6 x+8 y-11=0$

Pada indikator ini, sebagian besar siswa mampu menjawab soal dengan baik. Akan tetapi masih ditemukan dua orang siswa yang sama sekali tidak mengerjakan soal dan beberapa siswa yang mengerjakan namun masih melakukan kesalahan dalam mengerjakannya. Kesalahan yang dilakukan siswa dalam menjawab soal nomor 2 ini adalah kesalahan konsep dan operasi, seperti dapat dilihat pada Gambar 2 .

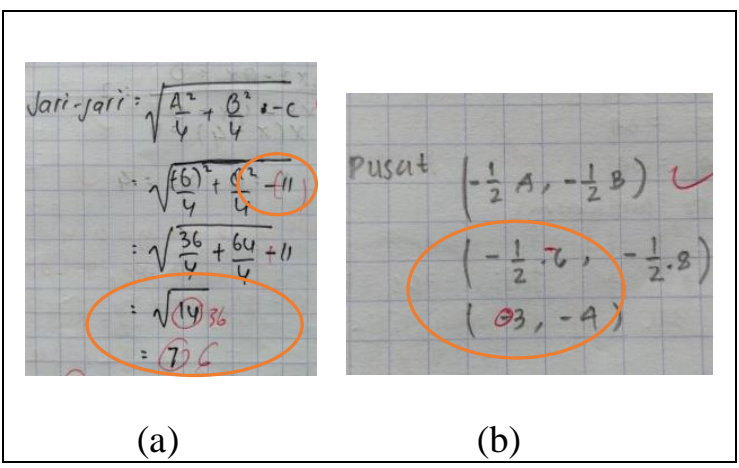

Gambar 2. Contoh Kesalahan Konsep dan Operasi pada Soal Nomor 2

Kesalahan operasi yang dilakukan siswa seperti pada Gambar 2 sering kali dilakukan siswa. Jika siswa melakukan kesalahan dalam pengoperasian di suatu langkah, akibatnya dapat mempengaruhi perhitungan pada langkah selanjutnya dan langkah akhir. Selain kesalahan operasi, terdapat kesalahan konsep yang dilakukan siswa ketika menjawab soal 
nomor 2. Pada Gambar 2 (a) siswa melakukan kesalahan dalam menentukan nilai $\mathrm{C}$ dari soal yang diberikan. Pada soal diberikan persamaan lingkaran $\mathrm{L} \equiv x^{2}+y^{2}-6 x+8 y-11=0$, yang mana nilai $\mathrm{C}$ dari persamaan lingkaran yang diberikan adalah (-11). Hal ini hampir sama dengan kesalahan yang dilakukan siswa pada Gambar 2 (b), yang mana nilai A dari persamaan lingkaran yang diberikan adalah ($6)$.

Indikator 3: Menentukan Kedudukan Suatu Garis Terhadap Lingkaran.

\section{Soal :}

3. Tentukan kedudukan garis $\mathrm{g} \equiv \mathrm{y}-\mathrm{x}+4=0$ terhadap lingkaran $\mathrm{L} \equiv x^{2}+y^{2}=16$. Jika berpotongan, tentukan titik potong garis terhadap lingkaran dan jika bersinggungan tentukan titik singgungnya.

Pada soal nomor 3, hampir semua siswa menjawab dengan benar namun, ada beberapa siswa mengerjakan soal dengan benar diawal, akan tetapi melakukan kesalahan operasi dan konsep pada langkah berikutnya. Kesalahan ini dapat dilihat pada Gambar 3 (a) dan (b).

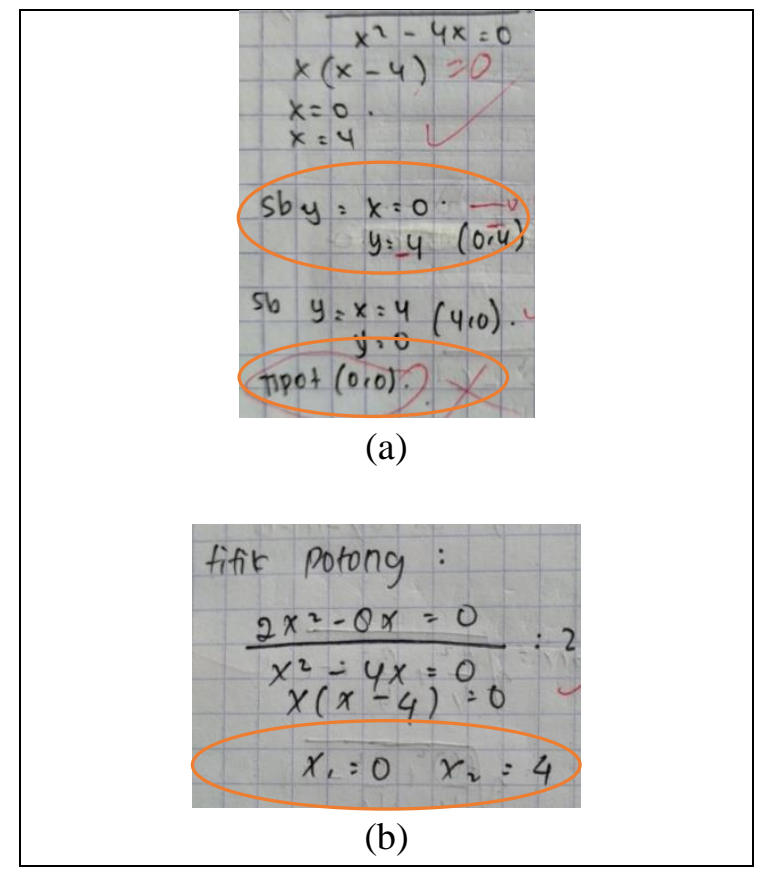

Gambar 3. Contoh Kesalahan Operasi dan Konsep pada Nomor 3

Pada Gambar 3 (a) siswa telah melakukan prosedur diawal dengan benar, akan tetapi ketika menentukan titik potong, siswa melakukan kesalahan operasi dan kesalahan dalam menyimpulkan di akhir. Jika kita perhatikan kembali soal yang diberikan, dikatakan bahwa jika garis dan lingkaran berpotongan maka tentukan titik potong garis terhadap lingkaran, berarti terdapat dua koordinat titik potong. sedangkan pada Gambar 3 (b), siswa hanya menentukan nilai absis koordinat titik potong saja.

Indikator 4: Menentukan persamaan garis singgung lingkaran yang berpusat di $(0,0)$ dengan jari-jari $r$ yang melalui sebuah titik $\left(x_{1}, y_{1}\right)$.

\section{Soal :}

4. Tentukan persamaan garis singgung lingkaran $\mathrm{L} \equiv x^{2}+y^{2}=34 \quad$ melalui titik B $(-3,5)$.

Pada soal nomor 4, siswa diminta untuk menentukan persamaan garis singgung lingkaran. Jika kita perhatikan dari soal yang diberikan, tampak jelas bahwa permasaan lingkaran yang diberikan adalah persamaan lingkaran yang berpusat di $(0,0)$. Namun, masih ditemukan tiga orang siswa yang melakukan kesaahan prinsip saat hendak menentukan persamaan garis singgung lingkarannya dan ada pula siswa yang melakukan kesalahan operasi seperti yang dapat dilihat pada Gambar 4.

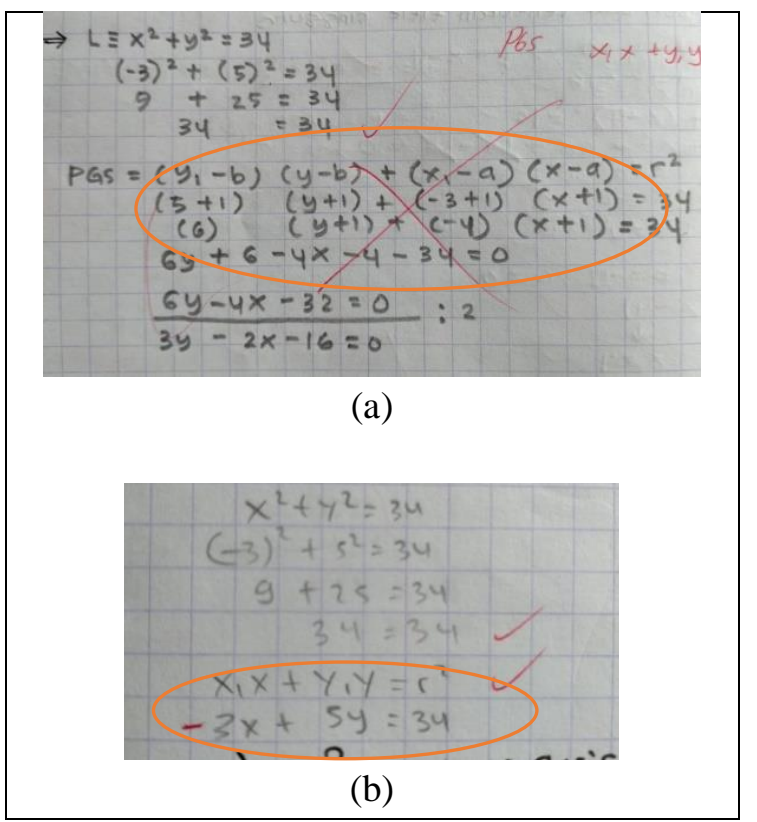

Gambar 4. Contoh Kesalahan Prinsip dan Operasi pada Nomor 4 
Langkah pengecekan awal yang dilakukan oleh siswa pada Gambar 4 (a) telah terbukti. Namun, siswa salah dalam menentukan pusat lingkaran. Siswa tidak menggunakan prinsip matematika dalam menentukan pusat lingkaran. Sehingga, seharusnya pusat lingkaran $(0,0)$ tetapi siswa menganggap pusat lingkaran $(-1,-1)$. Akibatnya, jawaban yang diperoleh siswa menjadi tidak tepat.

Indikator 5: Menentukan hubungan suatu lingkaran terhadap lingkaran lain.

\section{Soal :}

5. Selidiki hubungan lingkaran-lingkaran $L_{1} \equiv x^{2}+y^{2}=64$ dan $L_{2} \equiv x^{2}+y^{2}-$ $16 x-16 y+64=0 . \quad$ Jika kedua lingkaran tersebut berpotongan tentukan titik potong dan jika bersinggungan tentukan titik singgungnya.

Pada soal nomor 5 terlihat kesalahan konsep dan operasi yang dilakukan oleh siswa. Seperti yang dapat dilihat pada Gambar 5.

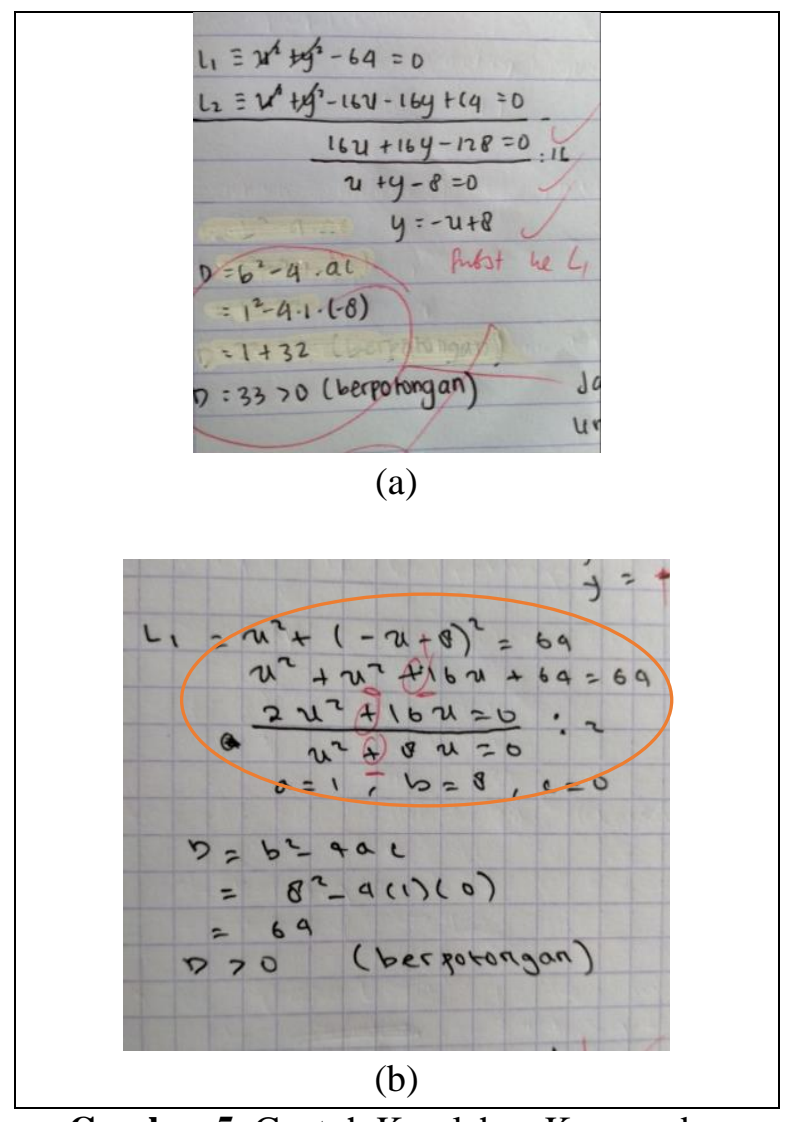

Gambar 5. Contoh Kesalahan Konsep dan Operasi pada soal nomor 5
Kesalahan yang dilakukan oleh beberapa siswa dalam menjawab soal nomor 5 diantaranya siswa tidak mensubstitusikan nilai $y=-x+8$ ke persamaan lingkaran $L_{1}$ seperti pada Gambar 5 (a). Kesalahan lain yang dilakukan siswa yaitu kesalahan dalam operasi seperti yang dapat dilihat pada Gambar 5 (b).

Indikator 6: Menentukan persamaan garis singgung lingkaran yang sejajar dengan sebuah garis.

\section{Soal :}

6. Tentukan persamaan garis singgung lingkaran $L \equiv x^{2}+y^{2}=17 \quad$ yang sejajar dengan garis $g \equiv y+4 x-3=0$ Pada nomor 6, kebanyakan siswa melakukan kesalahan yang hampir sama. Kesalahan yang dilakukan adalah kesalahan konsep, operasi dan fakta. Seperti yang dapat dilihat pada Gambar 6 berikut.

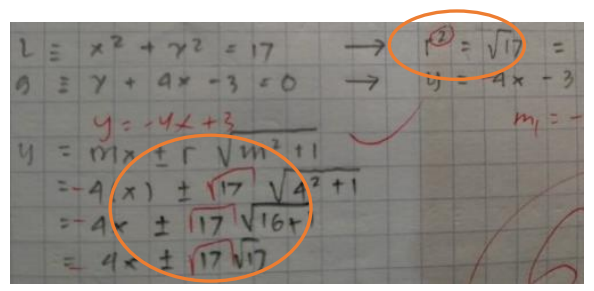

(a)

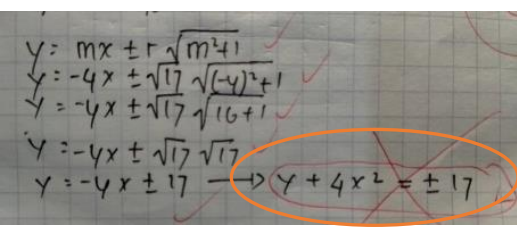

(b)

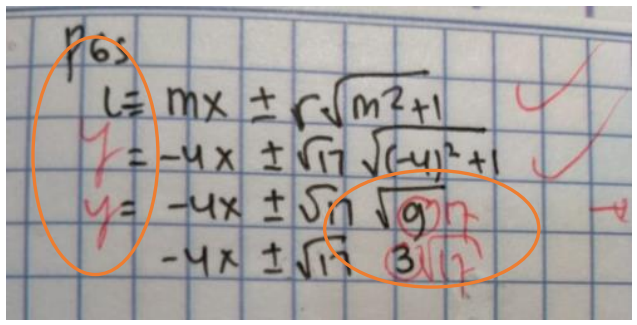

(c)

Gambar 6. Contoh kesalahan Konsep, Operasi dan Fakta pada soal nomor 6 
Pada Gambar 6 (a) dapat kita lihat kesalahan konsep yang dilakukan oleh siswa. Pada soal dikatakan bahwa $L \equiv x^{2}+y^{2}=17$, jadi, nilai dari $r^{2}=17$, berarti nilai dari $r=$ $\sqrt{17}$. Akan tetapi, siswa menuliskan jawaban $r^{2}=\sqrt{17}$. Kesalahan lain yang dilakukan siswa pada Gambar 6 (a) yaitu siswa salah memasukkan nilai $r$.

Pada Gambar 6 (b), jawaban yang ditulis oleh siswa telah benar, akan tetapi siswa melakukan kesalahan ketika hendak menjabarkan persamaan garis yang ia peroleh. Persamaan yang diperoleh siswa adalah $y=$ $-4 x \pm 17$. Seharusnya dari persamaan tersebut siswa akan mendapatkan dua persamaan garis yaitu $y=-4 x+17$ dan $y=$ $-4 x-17$.

Sedangkan pada Gambar 6 (c) siswa melakukan kesalahan operasi dan fakta. Simbol L digunakan siswa dalam jawabannya untuk menyatakan persamaan lingkaran, seharusnya symbol yang digunakan siswa adalah y. Selain itu, kesalahan siswa yaitu dalam menentukan hasil dari $\sqrt{(-4)^{2}+1}$, seharusnya $\sqrt{17}$, tetapi siswa menjawab $\sqrt{9}$.

Berdasarkan enam soal yang diberikan kepada siswa, masih terdapat kesalahan yang dilakukan siswa untuk masing-masing soal. Sebagian besar kesalahan yang dilakukan oleh siswa yaitu dalam menggunakan konsep dan operasi. Dari lima soal yang diberikan dapat disimpulkan bahwa sebagian besar kesalahan siswa disebabkan karena siswa kurang teliti dalam memahami dan mengerjakan soal. Oleh karena itu, sebaiknya guru mampu memahamkan dan mengingatkan siswa mengenai aturan pengoperasian aljabar. Guru juga harus menekankan kepada siswa untuk lebih teliti dalam mengerjakan soal.

Selain mendeskripsikan jenis kesalahankesalahan siswa dari hasil tes yang dilakukan, dipandang perlu untuk mengelompokkan jenis kesalahan berdasarkan kemampuan akademik siswa kelas XI MIPA 2 SMAN 1 Bangkinang Kota. Dalam Penggolongan tingkat kemampuan siswa, peneliti berpatokan pada KKM mata pelajaran matematika yang ditetapkan di SMAN 1 Bangkinang Kota, yaitu 75. Tingkat kemampuan siswa kelas XI MIPA 2 SMAN 1 Bangkinang Kota dapat dilihat pada tabel berikut.

Tabel 2. Penggolongan Tingkat Kemampuan Siswa

\begin{tabular}{cclccl}
\hline $\begin{array}{c}\text { Kode } \\
\text { Siswa }\end{array}$ & $\begin{array}{c}\text { Nilai } \\
\text { Tes }\end{array}$ & $\begin{array}{c}\text { Kemam } \\
\text {-puan }\end{array}$ & $\begin{array}{c}\text { Kode } \\
\text { Siswa }\end{array}$ & $\begin{array}{c}\text { Nilai } \\
\text { Tes }\end{array}$ & $\begin{array}{c}\text { Kemam } \\
\text {-puan }\end{array}$ \\
\hline S1 & 89 & Tinggi & S18 & 93 & Tinggi \\
S2 & 100 & Tinggi & S19 & 94 & Tinggi \\
S3 & 48 & Rendah & S20 & 93 & Tinggi \\
S4 & 100 & Tinggi & S21 & 47 & Rendah \\
S5 & 67 & Rendah & S22 & 38 & Rendah \\
S6 & 57 & Rendah & S23 & 41 & Rendah \\
S7 & 97 & Tinggi & S24 & 65 & Rendah \\
S8 & 100 & Tinggi & S25 & 68 & Rendah \\
S9 & 98 & Tinggi & S26 & 100 & Tinggi \\
S10 & 100 & Tinggi & S27 & 88 & Tinggi \\
S11 & 59 & Rendah & S28 & 43 & Rendah \\
S12 & 46 & Rendah & S29 & 75 & Sedang \\
S13 & 30 & Rendah & S30 & 98 & Tinggi \\
S14 & 70 & Rendah & S31 & 100 & Tinggi \\
S15 & 100 & Tinggi & S32 & 16 & Rendah \\
S16 & 96 & Tinggi & S33 & 79 & Sedang \\
S17 & 53 & Rendah & S34 & 62 & Rendah \\
\hline
\end{tabular}

Tabel 2 memperlihatkan bahwa siswa yang mencapai KKM berjumlah 18 orang $(52,94 \%)$. Terdapat 16 orang siswa berkemampuan tinggi $(47,06 \%), 2$ orang kemampuan sedang $(0,06 \%)$, dan 11 orang kemampuan rendah $(32,35 \%)$. Selanjutnya 7 orang siswa mendapatkan skor maksimal. yaitu 100 , sedangkan 1 orang siswa mendapat nilai terendah yaitu 16 .

Jika ditinjau berdasarkan gender maka tingkat kemampuan siswa berdasarkan jenis kelamin dapat dikelompokkan seperti pada Tabel 3 berikut.

Tabel 3. Pengelompokan Kemampuan Siswa Berdasarkan Jenis Kelamin

\begin{tabular}{clllll}
\hline $\begin{array}{c}\text { Kode } \\
\text { Siswa }\end{array}$ & $\begin{array}{c}\text { Kemam } \\
\text {-puan }\end{array}$ & JK & $\begin{array}{c}\text { Kode } \\
\text { Siswa }\end{array}$ & $\begin{array}{c}\text { Kemam } \\
\text {-puan }\end{array}$ & JK \\
\hline S1 & Tinggi & PR & S18 & Tinggi & PR \\
S2 & Tinggi & PR & S19 & Tinggi & PR \\
S3 & Rendah & LK & S20 & Tinggi & PR \\
S4 & Tinggi & PR & S21 & Rendah & PR \\
S5 & Rendah & LK & S22 & Rendah & LK \\
S6 & Rendah & LK & S23 & Rendah & PR \\
S7 & Tinggi & PR & S24 & Rendah & PR \\
S8 & Tinggi & LK & S25 & Rendah & LK \\
S9 & Tinggi & PR & S26 & Tinggi & LK \\
S10 & Tinggi & PR & S27 & Tinggi & PR \\
S11 & Rendah & PR & S28 & Rendah & PR \\
S12 & Rendah & PR & S29 & Sedang & LK \\
S13 & Rendah & LK & S30 & Tinggi & PR \\
S14 & Rendah & PR & S31 & Tinggi & LK \\
S15 & Tinggi & LK & S32 & Rendah & PR \\
S16 & Tinggi & PR & S33 & Sedang & PR \\
S17 & Rendah & LK & S34 & Rendah & PR \\
\hline
\end{tabular}


Catatan:

JK : Jenis Kelamin

PR : Perempuan

LK : Laki-laki

Tabel 3 menunjukkan bahwa 4 dari 16 siswa yang memiliki kemampuan tinggi merupakan siswa laki laki, sedangkan 12 orang lainnya adalah siswa perempuan. Rinciannya: $33,33 \%$ dari jumlah seluruh siswa laki-laki memiliki kemampuan tinggi, 8,33\% memiliki kemampuan sedang dan 58,33\% memiliki kemampuan rendah. Sedangkan untuk kemampuan siswa berdasarkan jenis kelamin perempuan, $36,36 \%$ dari jumlah seluruh siswa perempuan memiliki kemampuan tinggi, $4,54 \%$ berkemampuan sedang dan $40,9 \%$ berkemampuan rendah.

\section{SIMPULAN}

Hasil penelitian menunjukkan bahwa terdapat beberapa jenis kesalahan siswa yang dilakukan siswa dalam mengerjakan soal tes materi lingkaran yang telah diberikan pada siswa kelas XI MIPA 2 SMAN 1 Bangkinang Kota tahun ajaran 2019/2020. Jenis kesalahan pertama yang paling dominan dilakukan siswa dalam menjawab soal yang diberikan adalah kesalahan operasi. Hal ini karena kurang telitinya siswa menyelesaikan soal yang diberikan. Jenis kedua adalah kesalahan konsep yang terjadi pada konsep-konsep dasar untuk materi yang telah dipelajari sebelum mempelajari lingkaran. Dari kesalahan ini dapat terlihat dengan jelas bahwa dalam matematika, kesalahan dalam suatu konsep yang dipelajari sebalumnya dapat berpengaruh pada konsep-konsep yang akan dipelajari selanjutnya. Jenis ketiga adalah kesalahan prinsip yang dilakukan karena siswa tidak memahami maksud dan perintah soal sehingga siswa salah dengan menggunakan prinsip.

Setelah dilakukannya analisis terhadap kesalahan, salah satu upaya yang bisa dilakukan oleh guru adalah dengan melaksanakan Penelitian Tindakan Kelas (PTK) untuk memperbaiki dan meningkatkan kualitas pembelajaran di dalam kelas, sehingga membantu guru dalam meminimalisir terjadinya kesalahan-kesalahan yang dilakukan siswa dalam mengerjakan soal matematika.

\section{REKOMENDASI}

Berdasarkan hasil penelitian yang diperoleh, maka peneliti merekomendasikan hal berikut.

1. Siswa perlu diberi penekanan dalam memahami materi yang telah diajarkan, baik itu terkait fakta, konsep, prinsip dan operasi. Selain itu, siswa perlu memahami maksud dan perintah soal agar ketika menjawab soal siswa tidak bingung dalam menggunakan konsep dan prinsip. Siswa juga harus dibekali dengan ketelitian, selalu melakukan pengecekan ulang terhadap jawaban yang diperoleh agar tidak terjadi kesalahan dalam pengoperasian.

2. Guru diharapkan agar lebih memperdalam pemahaman siswa tentang materi prasyarat dan guru lebih menekankan lagi pemahaman konsep kepada siswa dalam mengerjakan soal sesuai indikator agar tidak terjadi kesalahan konsep. Selain itu, guru juga harus menekankan kepada siswa untuk melakukan pengecekan ulang terhadap jawaban mereka agar kesalahan dalam pengoperasian tidak terjadi.

\section{DAFTAR PUSTAKA}

Ariyana, T., Fera, M., \& Febrian, F. (2019). Analisis kesalahan siswa pada level multistructural berdasarkan taksonomi solo plus dalam menyelesaikan soal materi persamaan lingkaran. Lentera Sriwijaya: Jurnal Ilmiah Pendidikan Matematika, 1(1), 55-63. https://doi.org/10.36706/jls.v1i1.9569

Damayanti, N.W., Mayangsari, S. N., \& Mahardhika, L.T. (2017). Analisis kesalahan siswa dalam pemahaman konsep operasi hitung pada pecahan. Jurnal Ilmiah Edutic, 4(1), 1 - 7. https://doi.org/10.21107/edutic.v4i1.3389

Fitria, T.N. (2013). Analisis kesalahan siswa dalam menyelesaikan soal cerita berbahasa inggris pada materi persamaan dan pertidaksamaan linear satu variabel. MATHEdunesa, 2(1), $1-8$ 
Volume 2, Nomor 2, Mei 2020

DOI: https://doi.org/10.33578/prinsip.v2i2.53

jprinsip.ejournal.unri.ac.id

Hamdani. (2011). Strategi belajar mengajar. Pustaka Setia

Nurhazannah, Y. (2017). Meningkatkan hasil belajar siswa menggunakan model pembelajaran Kooperatif tipe Student Team Achievement Division (STAD). Jurnal Pendidikan Matematika dan IPA, 8(2), $\quad 50$ -

59. http://dx.doi.org/10.26418/jpmipa.v8i 2.21176

Rusman. (2016). Model-model pembelajaran mengembangkan profesionalisma guru. PT Rajagrafindo Persada

Saifudin, M. (2017). Analisis kesalahan siswa dalam menyelesaikan soal lingkaran kelas VIII SMP Muhammadiyah 2 Malang. Undergraduate (S1) thesis, University of Muhammadiyah Malang

Soedjadi, R. (2000). Kiat pendidikan matematika di indonesia konstatasi keadaan masa kini menuju harapan masa depan. Dirjen Dikti Depdiknas

Suhady, W., Roza, Y., \& Maimunah, M. (2019). Identifikasi kesalahan konseptual dan prosedural siswa dalam menyelesaikan soal pada materi dimensi tiga. Jurnal Cendekia: Jurnal Pendidikan Matematika, 3(2), 494-504
Sukmadinata, N. S. (2011). Metode penelitian pendidikan. PT Remaja Rosda Karya

Wijaya, A. A., \& Masriyah. (2013). Analisis kesalahan siswa dalam menyelesaikan soal cerita materi Sistem Persamaan Linear Dua Variabel. MATHEdunesa Jurnal Ilmiah Pendidikan Matematika, 2(1)

Zaini, M. (2010). Analisis kesalahan siswa dalam menyelesaikan soal-soal matematika pokok bahasan Trigonometri kelas XI MA Miftahul Qulub Polagan Galis Pamekasan Tahun Ajaran 20092010. Skripsi. Fakultas Keguruan Dan Ilmu Pendidikan. Universitas Madura

Zulfah. (2017). Analisis kesalahan peserta didik pada materi persamaan linear dua varibael di kelas VIII MTs Negeri Sungai Tonang. Jurnal Cendikia: Pendidikan Matematika, 1(1), $12 \quad$ - 16. https://doi.org/10.31004/cendekia.v1i1.4 